\title{
Pemberian Bisphenol A (BPA) Oral Menurunkan Kadar Superoksida Dismutase dan Meningkatkan Kadar F2-isoprostan pada Tikus Putih (Rattus norvegicus) Jantan Galur Sprague Dawley
}

\author{
${ }^{1}$ Yogie Sulaiman, ${ }^{2}$ IGM Aman, ${ }^{3}$ Wimpie Pangkahila
}

\author{
${ }^{1}$ Program Pascasarjana Anti-Aging Medicine \\ ${ }^{2}$ Departemen Farmakologi \\ ${ }^{3}$ Departemen Andrologi dan Seksologi \\ Fakultas Kedokteran Universitas Udayana Denpasar \\ E-mail: endorfin.08@gmail.com
}

\begin{abstract}
Bisphenol A (BPA), commonly found in plastic packaging and cans, can induce oxidative stress. This study was aimed to prove that oral BPA could decrease superoxide dismutase (SOD) and increase F2-isoprostan levels in male Sprague Dawley rats. This was an experimental study using randomized pretest-posttest control group design. There were 14 rats (Rattus norvegicus), male, Sprague Dawley strain, 8-10 weeks old, as subjects. Rats were divided into two groups with 7 rats each. The control group (P0) was treated with placebo for 21 days and the treatment group (P1) was treated with oral BPA dose of $400 \mathrm{mg} / \mathrm{kg}$ for 21 days. Before and after treatment for 21 days, blood was drained through the canthus medial sinus orbital and urine was collected as pretest and posttest data. SOD and F2-isoprostan levels were then examined by using ELISA. The results showed that before treatment (pretest), the mean SOD level in P0 group was $42.51 \pm 3.127 \mathrm{U} / \mathrm{mL}$ and in $\mathrm{P} 1$ group was $41.87 \pm 2.477 \mathrm{U} / \mathrm{mL}(P>0.05)$. The mean $\mathrm{F} 2-$ isoprostane level in P0 group was $3.18 \pm 0.599 \mathrm{ng} / \mathrm{ml}$ and in P1 group was $3.22 \pm 0.489 \mathrm{ng} / \mathrm{ml}(P>$ 0.05). However, after treatment for 21 days (posttest), the mean level of SOD in P0 group was $43.52 \pm 3.472 \mathrm{U} / \mathrm{mL}$ and in $\mathrm{P} 1$ group was $31.84 \pm 2.563 \mathrm{U} / \mathrm{mL}(P<0.01)$. The mean level of $\mathrm{F} 2-$ isoprostane in P0 group was $2.94 \pm 0.500 \mathrm{ng} / \mathrm{ml}$ and in P1 group was $4.47 \pm 0.241 \mathrm{ng} / \mathrm{ml}(P<0.01)$. The analysis of the treatment effect showed significant decreased level of SOD and increased level of F2-isoprostane in P1 group $(P<0.01)$. Conclusion: Oral bisphenol A could decrease superoxide dismutase (SOD) and increase F2-isoprostan levels in male Sprague dawley rats.
\end{abstract}

Keywords: bisphenol A (BPA), SOD, F2-isoprostane, Sprague Dawley rats

\begin{abstract}
Abstrak: Bisphenol A (BPA) banyak ditemukan dalam kemasan plastik dan kaleng dan dapat menyebabkan peningkatan radikal bebas. Penelitian ini bertujuan untuk membuktikan pemberian BPA oral dapat menurunkan kadar superoksida dismutase (SOD) dan meningkatkan kadar F2-isoprostan pada tikus (Rattus norvegicus) jantan galur Sprague Dawley. Jenis penelitian ialah eksperimental dengan randomized pretest-postest control group design yang menggunakan 14 ekor tikus (Rattus norvegicus) jantan, galur Sprague Dawley, berumur 8-10 minggu, yang terbagi menjadi 2 (dua) kelompok masing-masing berjumlah 7 ekor tikus. Kelompok kontrol (P0) diberikan plasebo selama 21 hari dan kelompok perlakuan (P1) diberikan BPA dosis $400 \mathrm{mg} / \mathrm{kgBB}$ selama 21 hari. Sebelum dan sesudah perlakuan selama 21 hari, darah diambil melalui chantus medial orbitalis dan urin dikumpulkan untuk pemeriksaan pretest dan postest. Kadar SOD dan F2-isoprostan diperiksa dengan metode ELISA. Hasil penelitian menunjukkan bahwa sebelum perlakuan (pretest), rerata kadar SOD

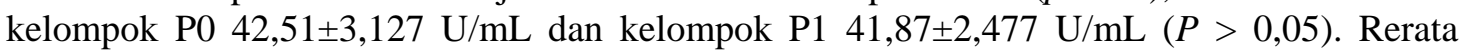
kadar F2-isoprostan kelompok P0 3,18 $\pm 0,599 \mathrm{ng} / \mathrm{ml}$ dan kelompok P1 3,22 $\pm 0,489 \mathrm{ng} / \mathrm{ml}(\mathrm{P}>$ $0,05)$. Setelah perlakuan selama 21 hari (posttest), rerata kadar SOD kelompok P0 $43,52 \pm 3,472 \mathrm{U} / \mathrm{mL}$ dan kelompok P1 31,84 $\pm 2,563 \mathrm{U} / \mathrm{mL}(P<0,01)$. Rerata kadar F2-

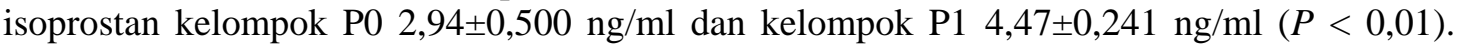


Analisis efek perlakuan menunjukkan terjadi penurunan kadar SOD dan peningkatan kadar F2-isoprostan yang bermakna pada kelompok P1 $(P<0,01)$. Simpulan: Bisphenol A oral dapat menurunkan kadar superoksida dismutase dan meningkatkan kadar F2-isoprostan pada tikus galur Sprague Dawley jantan.

Kata kunci: BPA, SOD, F2-Isoprostan, tikus Sprague Dawley

Bisphenol A (BPA) merupakan salah satu bahan kimia yang paling umum terpapar langsung pada manusia dalam kehidupan sehari-hari yang berasal dari monomer sintesis epoksi resin. Epoksi resin digunakan sebagai bahan pelapis dinding, dalam kemasan makanan dan minuman kaleng, perekat, pelapis pipa saluran air minum, serta komponen mobil atau pesawat terbang. Bisphenol A juga merupakan bahan dasar industri plastik polikarbonat yang sangat diperlukan dalam produksi compact disk (CD) dan CD-ROM, peralatan rumah tangga, kemasan makanan dan air mineral, botol minum bayi, dental sealant, pestisida, fungisida, bahan anti api, antioksidan, stabiliser dalam produksi polyvynyl chloride (PVC), dan bahkan dalam sintesis hidrokuinon. Penggunaan epoksi resin ini bertujuan untuk mencegah terjadinya korosi atau reaksi bahan pengemas dengan pangan yang ada di dalamnya. ${ }^{1}$

Bisphenol A merupakan senyawa tidak stabil dan juga lipofilik; oleh karena itu BPA dapat larut dalam produk makanan, terutama ketika dipanaskan. Setelah berada dalam makanan, BPA dapat masuk ke dalam tubuh dengan cepat khususnya anakanak. Berbagai penelitian membuktikan terjadinya peningkatan kadar BPA dalam sampel urin dan darah yang diambil dari subjek penelitian yang mengonsumsi makanan dan minuman yang dikemas dalam produk yang mengandung $\mathrm{BPA}^{2,3}$ Penelitian lain menunjukkan bahwa dengan membatasi asupan makanan kemasan dalam waktu tiga hari didapatkan penurunan konsentrasi BPA yang ditemukan dalam urin dengan rerata $65 \%{ }^{4}$

Dalam bentuk aktif, senyawa BPA memiliki aktivitas hormon estrogen sehingga jika masuk ke dalam tubuh dapat meniru kerja hormon estrogen. Oleh karena itu para peneliti memberikan perhatian yang cukup besar terhadap BPA dan kemungkinan efeknya terhadap manusia. Selain itu, BPA juga merupakan salah satu senyawa endocrine disruptors yang dapat mengganggu biosintesis, sekresi, kerja, atau metabolisme alami suatu hormon. ${ }^{5}$ Studi baru-baru ini menunjukkan bahwa paparan BPA dalam jangka waktu yang lama berhubungan dengan peningkatan penyakit yang berhubungan dengan penuaan. Menurut Tan et al. ${ }^{6}$ dalam penelitiannya tentang paparan BPA $4 \mu \mathrm{g} / \mathrm{kg} \quad \mathrm{BB}$ meningkatkan aging process pada nematode Caenorhabbditis elegans. ${ }^{6}$ Selain sebagai endocrine disruptors, belakangan ini penelitian menunjukkan bahwa BPA juga dapat menyebabkan penuaan melalui peningkatan senyawa radikal di dalam tubuh dan menginduksi terjadinya stres oksidatif. Dilaporkan bahwa BPA meningkatkan produksi reactive oxygen species (ROS), menyebabkan kerusakan hati, dan disfungsi mitokondria., Bisphenol A juga menyebabkan penurunan motilitas sperma epididimis dan jumlah sperma. Hasil penelitian ini menunjukkan bahwa BPA menginduksi stres oksidatif pada sperma epididimis tikus. ${ }^{9}$

Sehubungan dengan potensi toksisitas senyawa radikal bebas, tubuh memiliki tiga enzim antioksidan intrasel atau antioksidan endogen, yaitu superoksida dismutase (SOD), glutation peroksidade (GPx), dan katalase (Cat). Superoksida dismutase merupakan salah satu antioksidan endogen yang berfungsi mengatalisis reaksi dismutasi radikal bebas anion superoksida $\left(\mathrm{O}^{2-}\right)$ menjadi hidrogen peroksida dan molekul oksigen. ${ }^{10}$ Hasil penelitian menunjukkan bahwa stres oksidatif secara bermakna menurunkan SOD CuZn dan SOD Mn. Hal ini dikarenakan enzim antioksidan seperti SOD berperan untuk 
mengikat radikal bebas dan mengubahnya menjadi bentuk yang tidak berbahaya. ${ }^{11}$

Kondisi stres oksidatif dapat dideteksi dengan menggunakan indikator F2isoprostan (8-iso-PGF2 $\alpha$ ) yang merupakan hasil dari peroksidase lipid membran sel di dalam tubuh akibat radikal bebas. ${ }^{12}$ F2isoprostan ialah komponen prostaglandin -like yang terbentuk dari katalisis peroksidasi radikal bebas dari asam lemak esensial (primarily arachidonic acid) tanpa perintah atau aksi langsung dari enzim cyclooxygenase (COX). F2-isoprostan merupakan eicosanoids non klasikal dan memiliki aktivitas biologik poten sebagai mediator inflamasi yang menimbulkan persepsi nyeri. F2-isoprostan merupakan indikator yang akurat dari peroksidasi lipid baik pada manusia maupun hewan dalam konteks terjadinya stres oksidatif. ${ }^{13}$

\section{METODE PENELITIAN}

Jenis penelitian ini ialah eksperimental dengan menggunakan randomized pretestposttest control group design. ${ }^{14}$ Subjek penelitian ialah 14 ekor tikus putih (Rattus norvegicus) jantan, galur Sprague Dawley berumur 8-10 minggu, berat badan \pm 150 160 gram, dan sehat; yang dibagi menjadi 2 kelompok, masing-masing berjumlah 7 ekor tikus. Satu kelompok sebagai kelompok kontrol yang diberikan plasebo (P0) selama 21 hari dan kelompok lainnya ialah kelompok perlakuan yang diberi bisphenol A (P1) dosis $400 \mathrm{mg} / \mathrm{kg}$ BB tikus selama 21 hari. Sebelum penelitian dimulai, tikus diadaptasi selama satu minggu di tempat penelitian untuk penyesuaian dengan lingkungan. Pada hari ke-8, diambil sampel darah melalui canthus medial orbitalis dan dikoleksi urin semalam untuk pemeriksaan pretest. Tikus kemudian dibagi menjadi dua kelompok. Setelah 21 hari perlakuan sesuai dengan kelompoknya, diambil sampel darah melalui canthus medial orbitalis dan dikoleksi urin semalam untuk pemeriksaan posttest. Aktivitas SOD diukur dengan menggunakan spektro-fotometri dan SOD Assay Kit (Biovision) sedangkan F2isoprostan diukur dengan menggunakan metode 8-iso-prostaglandin F2 $\alpha$ yang merupakan enzyme immunoassay kit (EIA) dari assay design menggunakan metode spektrometri.

\section{HASIL DAN BAHASAN}

Hasil penelitian menunjukkan sebelum perlakuan (pretest) rerata kadar SOD kelompok P0 42,51 $\pm 3,127 \quad \mathrm{U} / \mathrm{mL}$ dan kelompok P1 41,87 $\pm 2,477 \mathrm{U} / \mathrm{mL}(P>0,05)$. Rerata kadar F2-isoprostan kelompok P0 $3,18 \pm 0,599 \mathrm{ng} / \mathrm{ml}$ dan kelompok P1 3,22 $\pm 0,489 \mathrm{ng} / \mathrm{ml}(P>0,05)$. Setelah perlakuan selama 21 hari (posttest), rerata kadar SOD kelompok P0 43,52 $\pm 3,472$ $\mathrm{U} / \mathrm{mL}$ dan kelompok P1 31,84 $\pm 2,563 \mathrm{U} / \mathrm{mL}$ $(P<0,01)$. Rerata kadar $\mathrm{F} 2$-isoprostan kelompok P0 2,94 $\pm 0,500 \mathrm{ng} / \mathrm{ml}$ dan

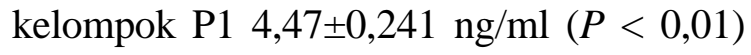
(Tabel 1).

Tabel 1. Perbandingan rerata kadar SOD dan F2-isoprotan antar kelompok

\begin{tabular}{|c|c|c|c|c|c|c|c|}
\hline Pemeriksaan & Variabel & Kelompok & $\mathbf{n}$ & Rerata & SB & $t$ & $P$ \\
\hline \multirow[t]{4}{*}{ Pretest } & \multirow[b]{2}{*}{$\mathrm{SOD}(\mathrm{U} / \mathrm{mL})$} & P0 & 7 & 42,51 & 3,127 & \multirow{2}{*}{0,429} & \multirow[b]{2}{*}{0,675} \\
\hline & & $\mathrm{P} 1$ & 7 & 41,87 & 2,477 & & \\
\hline & \multirow{2}{*}{$\begin{array}{l}\text { F2-Isoprostan } \\
\text { (ng/mL) }\end{array}$} & P0 & 7 & 3,18 & 0,599 & \multirow{2}{*}{$-0,142$} & \multirow{2}{*}{0,890} \\
\hline & & $\mathrm{P} 1$ & 7 & 3,22 & 0,489 & & \\
\hline \multirow{4}{*}{ Posttest } & \multirow{2}{*}{$\mathrm{SOD}(\mathrm{U} / \mathrm{mL})$} & P0 & 7 & 43,52 & 3,472 & \multirow{2}{*}{7,166} & \multirow{2}{*}{0,000} \\
\hline & & $\mathrm{P} 1$ & 7 & 31,84 & 2,563 & & \\
\hline & F2-Isoprostan & P0 & 7 & 2,94 & 0,500 & \multirow{2}{*}{$-7,272$} & \multirow{2}{*}{0,000} \\
\hline & $(\mathrm{ng} / \mathrm{mL})$ & P1 & 7 & 4,47 & 0,241 & & \\
\hline
\end{tabular}

$\mathrm{n}=$ jumlah sampel; $\mathrm{SB}=$ Simpangan Baku; $t=$ distribusi $\mathrm{t}$ hitung; $P=$ signifikansi 
Untuk membuktikan efek perlakuan masing-masing kelompok terhadap variabel penelitian, dilakukan analisis efek perlakuan dengan menggunakan t-paired test. Hasil menunjukkan tidak terjadi perubahan kadar SOD maupun F2isoprostan pada kelompok kontrol $(P>$
0,05), namun pada kelompok perlakuan (P1) yang diberikan BPA oral dosis 400 $\mathrm{mg} / \mathrm{kgBB}$ selama 21 hari menunjukkan penurunan kadar SOD dan peningkatan kadar F2-isoprostan yang sangat bermakna $(P<0,01)$ (Tabel 2).

Tabel 2. Perbandingan pretest-posttest rerata nilai variabel masing-masing kelompok

\begin{tabular}{llcccc}
\hline \multirow{2}{*}{ Variabel } & \multirow{2}{*}{ Kelompok } & \multicolumn{2}{c}{ Rerata Nilai } & \multirow{2}{*}{ T } & \multirow{2}{*}{ P } \\
\cline { 3 - 4 } & & Sebelum & Sesudah & & \\
\hline \multirow{2}{*}{ Kadar SOD (U/mL) } & Kontrol (P0) & $42,51 \pm 3,127$ & $43,52 \pm 3,472$ & $-0,583$ & 0,581 \\
& Perlakuan (P1) & $41,87 \pm 2,477$ & $31,84 \pm 2,563$ & 9,697 & 0,000 \\
\hline Kadar F2- & Kontrol (P0) & $3,18 \pm 0,599$ & $2,94 \pm 0,500$ & 0,929 & 0,389 \\
isoprostan (ng/mL) & Perlakuan (P1) & $3,22 \pm 0,489$ & $4,47 \pm 0,241$ & $-5,706$ & 0,000 \\
\hline
\end{tabular}

$\mathrm{t}=\mathrm{t}$ hitung; $\mathrm{p}=$ signifikansi

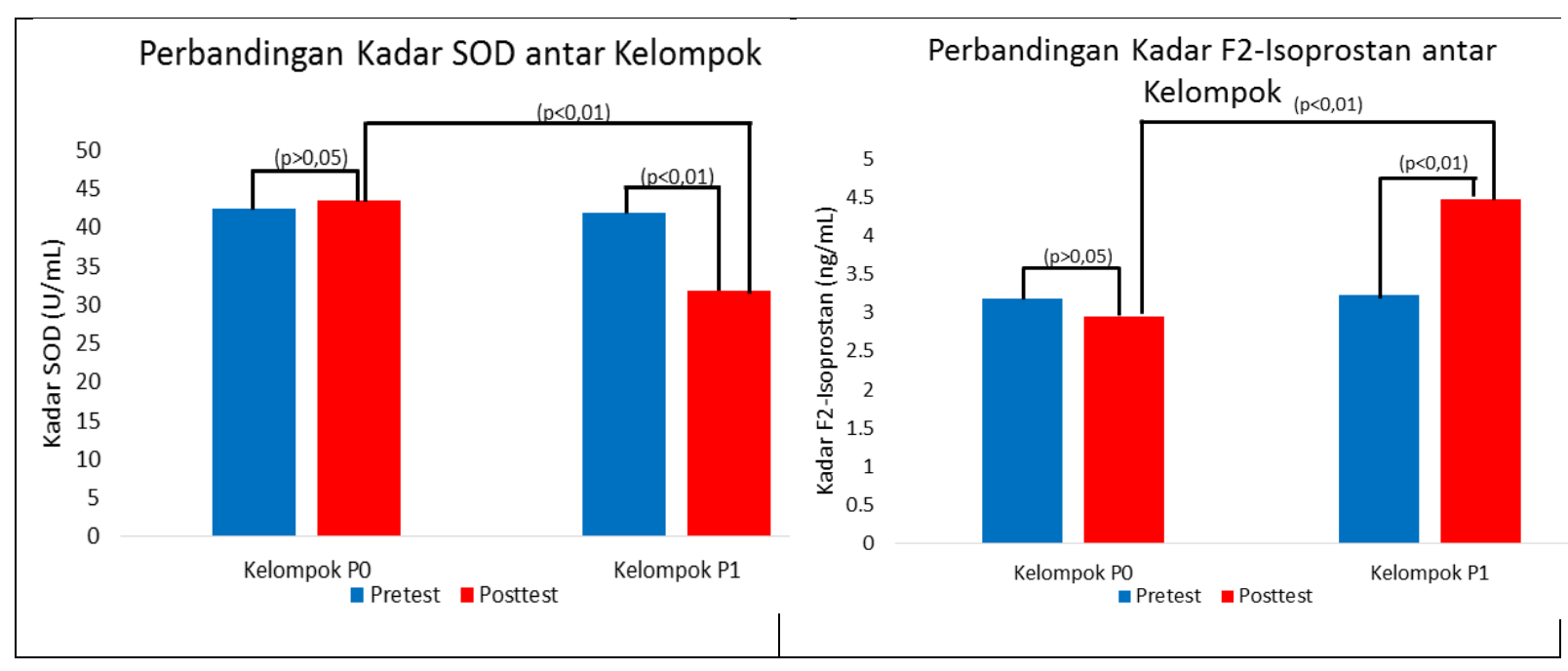

Gambar 1. Perbandingan kadar SOD dan F2-isoprostan antar kelompok

Bisphenol A dapat menyebabkan penuaan dan menginduksi terjadinya penyakit degeneratif karena senyawa ini meningkatkan radikal bebas dan menyebabkan stres oksidatif. Hasil penelitian ini menunjukkan bahwa pemberian BPA oral dosis $400 \mathrm{mg} / \mathrm{kgBB}$ selama 21 hari dapat menurunkan kadar SOD dan meningkatkan kadar F2isoprostan yang bermakna dari nilai baseline sebelum perlakuan $(P<0,01)$. Dalam penelitian ini digunakan SOD sebagai parameter yang menggambarkan kondisi pertahanan intrasel terhadap stres oksidatif. Terdapat tiga jenis antioksidan enzimatik endogen di dalam tubuh, yaitu SOD, glutation (GSH) dan katalase, namun dalam penelitian ini digunakan SOD karena SOD memiliki waktu paruh (half-life) yang paling panjang dibandingkan dengan GSH dan katalase sehingga dapat menggambarkan kondisi pertahanan terhadap stres oksidatif yang lebih akurat. ${ }^{15}$ Selain itu SOD merupakan antioksidan enzimatik yang berperan paling pertama dan dominan terhadap kerusakan oksidatif akibat ROS. ${ }^{16}$ Telah diketahui bahwa SOD merupakan antioksidan enzimatik dengan jumlah yang 
paling besar dan terlokalisasi pada hampir seluruh kompartemen sel. ${ }^{15}$ Selain itu SOD juga banyak terdapat pada matriks ekstrasel jaringan dan serum dengan aktivitas enzimatik yang paling tinggi. ${ }^{17}$

Hasil penelitian ini didukung oleh beberapa penelitian terdahulu. Penelitian menunjukkan bahwa BPA menyebabkan hepatotoksisitas dengan menurunkan aktivitas enzim antioksidan (SOD, CAT, GPX), dan meningkatkan kadar NO dan MDA, serta secara bermakna menurunkan kapasitas antioksidan total dalam tubuh pada tikus. ${ }^{18}$ Selain itu dilaporkan bahwa BPA meningkatkan produksi ROS serta menyebabkan kerusakan hati dan disfungsi mitokondria. ${ }^{7,8}$ BPA juga menyebabkan penurunan motilitas sperma epididimis dan jumlah sperma melalui induksi stres oksidatif pada sperma epididimis tikus. ${ }^{9}$ Penelitian lain juga menunjukkan bahwa injeksi BPA dapat meningkatkan kadar MDA yang merupakan biomarker peroksidasi lipid, penurunan kadar GSH dan TAS, serta menghambat aktivitas SOD dan CAT pada pankreas tikus dibandingkan dengan kelompok kontrol $(P<0,05)$, sehingga paparan BPA mungkin dapat menyebabkan hiperglikemia dan komplikasi terhadap patogenesis diabetes pada tikus jantan dewasa. ${ }^{19}$ Penelitian lain menyebutkan bahwa pemberian BPA yang meningkatkan produksi radikal oksigen dan nitrogen yaitu ROS dan NO, dapat menggangu fungsi limfosit $\mathrm{T}$, menurunkan ekspresi interleukin, menghambat jalur sinyal molekul TLR4/NF- $\kappa \mathrm{B}$, dan berefek imunosupresi. ${ }^{20}$ Hal yang sama dilaporkan juga pada penelitian in vitro menggunakan kultur sel ginjal bahwa pemberian BPA jangka pendek (6 jam) dapat menurunkan ekspresi gen glutation dan SOD. ${ }^{21}$

SOD melindungi jaringan dari stres oksidatif dan kerusakan oleh radikal bebas dengan mengkatalisis konversi $\mathrm{O}_{2}{ }^{-}$untuk $\mathrm{H}_{2} \mathrm{O}_{2}$, sehingga ROS di dalam sel menjadi lebih stabil. Kerusakan pada tingkat sel oleh oksidan dilemahkan oleh enzim antioksidan seperti SOD, GSHPx, GSP, CAT, dan GR. ${ }^{22}$ BPA menyebabkan penurunan bermakna dalam tingkat GSH, bersamaan dengan penurunan aktivitas SOD telah ditunjukkan oleh Hassan et al. ${ }^{23}$ Selain itu hasil penelitian ini juga ditegaskan oleh hasil penelitian $\mathrm{Wu}$ et al. ${ }^{24}$ yang menunjukkan penurunan bermakna dalam tingkat GSH dan SOD pada kelompok tikus yang diberikan BPA.

Antioksidan dapat mengurangi kerusakan sel yang dihasilkan oleh interaksi antara lipid, protein, dan DNA dengan ROS. Terlepas dari kemampuan sistem antioksidan endogen, ketidakseimbangan produksi ROS akibat bahan kimia dapat mengakibatkan sejumlah gangguan klinis. BPA dapat menyebabkan stres oksidatif dengan mengganggu status redoks dalam sel. ${ }^{25}$

Hingga saat ini belum ada penelitian yang menjelaskan bagaimana mekanisme kerja BPA dalam menginduksi stres oksidatif. Telah terdapat penelitian, termasuk penelitian ini, yang membuktikan bahwa BPA dapat menurunkan aktivitas antioksidan endogen baik enzimatik maupun non enzimatik, salah satunya yang telah diukur ialah didapatkannya penurunan kadar SOD pada darah tikus putih (Rattus norvegicus) galur Sprague Dawley jantan. Penurunan kadar SOD ini diduga disebabkan karena BPA berperan sebagai radikal bebas. Bisphenol A dalam jumlah besar akan membuat tubuh tidak dapat melakukan kompensasi sehingga terjadi penurunan kadar SOD. Kondisi tersebut menyebabkan peningkatan radikal bebas dalam sel serta menyebabkan kerusakan sel dan jaringan di dalam tubuh. Kerusakan pada sel termasuk di dalamnya kerusakan membran sel melalui peroksidasi lipid membran sel. Proses ini akan melepaskan mediator inflamasi, salah satunya ialah F2isoprostan dan hasil pengukuran adanya peningkatan kadar F2-isoprostan sebagai parameter terjadinya stres oksidatif. Secara garis besar, paparan terhadap BPA dapat mempercepat proses penuaan melalui induksi kerusakan oksidatif.

\section{SIMPULAN}

Berdasarkan hasil penelitian ini dapat disimpulkan bahwa pemberian bisphenol-A 
dapat menurunkan kadar SOD dan meningkatkan kadar F2-isoprostan pada tikus putih jantan galur Sprague Dawley.

\section{DAFTAR PUSTAKA}

1. Peretz J, Vrooman L, Ricke WA, Hunt PA, Ehrlich S, Hauser R, et al. Bisphenol $\mathrm{A}$ and reproductive health: update of experimental and human evidence 2007-2013. Environ Health Perspect. 2014;122(8):775-86.

2. Carwile J, Luu H, Bassett L, Driscoll D, Yuan C, Chang J, et al. 2009. Polycarbonate bottle use and urinary bisphenol A concentrations. Environ Health Persp. 2009;117(9):1368-72.

3. Smith-Bindman R, Lipson J, Marcus R, Kim K, Mahesh M, Gould R, et al. Radiation dose associated with common computed tomography examinations and the associated life time attributable risk of cancer. Arch Intern Med. 2009;169:2078-86.

4. Rudel RA, Fenton SE, Ackerman JM, Euling SY, Makris SL. Environmental exposures and mammary gland development: state of the science, public health implications, and research recommendations. Environ Health Persp. 2011;119(8):1053-61.

5. Sipahutar H, Gaol A, Silalahi A. Akselerasi pencapaian pubertas mencit setelah pendedahan xenoestrogen bisphenol A (BPA) selama dua generasi berturutturut. J Sains MIPA. 2007;89(2):95105.

6. Tan L, Wang S, Wang Y, He M, Liu D. Bisphenol A exposure accelerated the aging process in the nematode Caenorhabditis elegans. Toxicology Letters.2015;235:75-83.

7. Asahi J, Kamo H, Baba R, Doi Y, Yamashita A. Bisphenol A induces endoplasmic reticulum stressassociated apoptosis in mouse nonparenchymal hepatocytes. Life Sci. 2010;87: 431-8.

8. Moon MK, Kim MJ, Jung IK, Koo YD, Ann HY, Lee KJ, et al. Bisphenol A impairs mitochondrial function in the liver at doses below the no observed adverse effect level. J Korean Med Sci. 2012;27:644-52.

9. Chitra KC, Latchoumycandane C, Mathur PP. Induction of oxidative stress by bisphenol A in the epididymal sperm of rats. Toxicology. 2003;185(1-2):11927.

10. Halliwell B. Reactive spesies and antioxidants: Redox biology is a fudamental theme of aerobic life. Plant Physiol. 2006;141:312-22.

11. Vaziri ND, Wang XQ, Oveisi F, Rad B. Induction of oxidative stress by glutathione depletion causes severe hypertension in normal rats. Hypertension. 2000;36(1):142-6.

12. Hanak D. Isoprostane lipid peroxidation. 2010. [cited 2015 Sept 22]. Available from

http://www.kronoslaboratory.com/dot netnuke/FeaturedAssays/

Isoprostanes/tabid/130/Default.aspx.

13. Morrow JD, Frei B, Longmire AW, Gaziano JM, Lynch SM, Shyr Y, et al. Increase in circulating products of lipid peroxidation $\left(\mathrm{F}_{2}\right.$-Isoprostanes) in smokers - smoking as cause of oxidative damage. $\mathrm{N}$ Engl $\mathrm{J}$ Med. 1995;332:1198-203.

14. Pocock SJ. The size of a clinical trial in: clinical trial, a practical approach. Chichester: John Willey and Sons, 2008; p. 123-41.

15. Pandey KB, Rizvi SI. Markers of oxidative stress in erythrocytes and plasma during aging in humans. Oxid Med Cell Longev. 2010;3(1):2-12.

16. Fernández C, San Miguel E, FernándezBriera A. Superoxide dismutase and catalase: tissue activities and relation with age in the long-lived species Margaritifera margaritifera. Biol Res. 2009;42(1):57-68.

17. Chang D, Zhang $X$, Rong $S$, Sha $Q$, Liu $P$, Han $T$, et al. Serum antioxidative enzymes levels and oxidative stress products in age-related cataract patients. Oxid Med Cell Longev. 2013;2013:587826.

18. Eid JI, Eissa SM, El-Ghor AA. Bisphenol A induces oxidative stress and DNA damage in hepatic tissue of female rat offspring. JOBAZ. 2015;71:10-9.

19. Moghaddam HS, Samarghandian S, Farkhondeh T. Effect of bisphenol A on blood glucose, lipid profile and oxidative stress indices in adult male mice. Toxicol Mech Methods. 2015;25(7):507-13. 
20. Tao S, Zhang Y, Yuan C, Gao J, Wu F, Wang Z. Oxidative stress and immunotoxic effects of bisphenol A on the larvae of rare minnow Gobiocypris rarus. Ecotoxicol Environ Saf. 2016;124:377-85.

21. Yazdani M, Andresen AM, Gjoen T. Shortterm effect of bisphenol-a on oxidative stress responses in Atlantic salmon kidney cell line: a transcriptional study. Toxicol Mech Methods. 2016;26(4):295-300.

22. Koc A, Duru M, Ciralik H, Akcan R, Sogut S. Protective agent, erdosteine, against cisplatin-induced hepatic oxidant injury in rats. Mol Cell Biochem. 2005;278(12):79-84.
23. Hassan ZK, Elobeid MA, Virk P, Al Omer S, Amin ME, Daghestani MH, Al Oylayan EM. Bisphenol A induces hepatotoxicity through oxidative stress in rat model. Oxidative Medicine and Cellular Longevity. 2012;2012:194829.

24. Wu M, Xu H, Shen Y, Qiu W, Yang M. Oxidative stress in zebrafish embryos induced by short-term exposure to bisphenol A, nonylphenol, and their mixture. Environmental Toxicology and Chemistry. 2011;30(10):233541.

25. Hasselberg L, Meier S, Svardal A. Effects of alkylphenols on redox status in first spawning Atlantic cod (Gadus morhua). Aquat Toxicol. 2004;69:95105. 